\title{
International Trade Sanctions related to Dual-Use Goods and Technologies
}

\author{
By Ilaria Anna Colussi*
}

One of the basic rules in trade law is the freedom of trade. However, such rule encounters some limitations when the object of trade is constituted by strategic items, such as dual-use items, which may have peaceful (civilian/commercial) or non peaceful/military applications. Trade of these categories of goods needs to be controlled, as they can provoke security concerns. Such control is pursued through control lists, licenses, authorizations to stakeholders of the supply chain, informationsharing and cooperation mechanisms, reports, records, declarations, screenings and sanctions as well. The paper aims at focusing on the issue of sanctions, in particular the ones established at the international level: these measures are provided for the violation of trade rules in reference to dual-use items, and/or sanctions have as an object this type of goods. The legal provisions established by the World Trade Organization (WTO) and at the United Nations level are analysed thereafter. Brief observations are offered as regards the EU framework of restrictive measures too.

Keywords: Dual-use items; sanctions; embargoes; GATT; United Nations.

\section{Introduction}

International trade is mainly characterised by the principles of liberalization and free trade. Yet, economic or non-economic reasons can interfere with such rule and require the provision of limitations and exceptions.

Within non-economic reasons, there are the security ones, i.e. cases in which the foreign policy or political needs cross the purely economic instances, and they entail restrictions to trade. This occurs, for instance, in the hypothesis of strategic and 'sensitive' items, such as dual-use goods and technologies.

It is not an easy task to define what 'dual-use' means. ${ }^{2}$ However, there is a common understanding that the term refers to goods having either peaceful (civilian/commercial) or non peaceful/military applications. They are Weapons of Mass Destruction related items (chemical, biological, nuclear materials that could be used for proliferation purposes), or arms related items, or items linked to the control of information and communication (such as delivery systems and surveillance technology used for human rights abuses).

\footnotetext{
* PhD, Post-Doctoral fellow BeIPD-COFUND-IPD 2014 Marie Curie Postdoctoral Fellow, European Studies Unit, Department of Political Science, University of Liège, Belgium.

2 In this context, we make reference to 'dual-use' as applied to Weapons of Mass Destruction (WMD) export controls, keeping aside the broader notion of 'dual-use dilemma', which means that a research or its applications may be used for civilian uses or for building weapons and other military purposes.
} 
The control of these items shall cover the whole supply chain, including design, development, production, possession, delivery, transport, transit, transshipment, financing, brokering, exports, re-exports, transfers and imports of goods. The ways for pursuing the control of dual-use goods can consist of granting or denying licenses and authorizations to stakeholders, promoting information-sharing and cooperation mechanisms, such as through reports, records, declarations, screenings, and imposing sanctions in case of violation of trade control rules. Therefore, the issue of sanctions is a relevant component of control of dual-use goods.

This paper aims at analyzing sanctions related to dual-use goods, in particular the international ones (with the addition of brief observations on the EU framework).

\section{International Sanctions}

International sanctions for the trade of dual-use items are mainly imposed at the level of the United Nations (UN). Indeed, the Security Council (SC) has intervened against the threat of peace and security through trade measures covering dual-use goods as well.

Furthermore, at the international level, an organization that has dealt with the possibility of economic measures for non-economic reasons is the World Trade Organization (WTO): it should be observed, though, that the WTO itself has never imposed those sanctions as such upon States, but it has allowed States introducing them at the national level, by giving them the legal basis for doing so. Moreover, it has confirmed and strengthened the UN interventions, even if the legal basis and the legitimacy for the UN sanctions derive from the UN Charter, and not from the WTO rules.

So, internationally speaking, dual-use sanctions are: (a) justified under the General Agreements on Tariffs and Trade (GATT) system, which is part of the WTO framework, and (b) imposed by the Security Council in the form of embargoes or trade restrictions for peace and security purposes.

These two frameworks (the GATT/WTO and the UN one) will be considered thereafter in their features and effects. A critical examination will be offered too.

\section{The GATT Framework: Art. XXI}

Since 1947 when the GATT was established in Geneva by 23 initial countries, in order to foster a new international economic cooperation after the disasters of the World War II $^{3}$ the approach towards trade law was characterised by liberalization and free trade. These remain still now the basic principles of international trade: indeed, the World Trade Organization (WTO),

\footnotetext{
${ }^{3}$ Irwin, Mavroidis and Sykes (2009).
} 
born in 1997 on the basis of GATT and currently having 162 members ${ }^{4}$, has adopted them as essential rules in all the agreements related to goods, services, and intellectual property rights (i.e., the GATT, the General Agreement on Trade in Services (GATS) and the Trade-Related Aspects of Intellectual Property Rights (TRIPS)), as well as in agreements dealing with specific sectors or issues, such as agriculture, sanitary and phytosanitary measures, trade related investment measures, etc., and plurilateral trade agreements about trade civil aircrafts and public procurements.

The WTO has focused on cases in which security reasons compete with economic liberalism, thus introducing an exception for trade bans and limitations taken for non-economic and political motivations. The provision of reference is article XXI of the GATT. ${ }^{5}$ It is known as 'security exception', which "embraces five broad categories: (1) national security information; (2) nuclear material; (3) military goods and services; (4) war and international emergencies; and (5) UN Charter obligations". 6

Such provision allows States to invoke security reasons for justifying limitations to trade. In general terms, the provision permits derogation with any article of the GATT itself, as it is an all-embracing norm.

\section{Subjective Categories: Letters (a) and (b)}

Letter (a) allows for derogation of GATT principles for denying furnishing "information" linked to security interests. Thus, the WTO Member is free to define its security needs and to refuse to disclose sensitive information, provided that it informs other States, to the fullest extent possible, of the measures taken under art. XXI. This provision has been invoked only in the case of US restriction on export of strategic goods. Czechoslovakia requested to specify the items considered as strategic, but the US refused on the basis of art. XXI (a). ${ }^{7}$ This letter could permit trade restrictions on information concerning dual-use items too.

As for letter (b), it is subdivided into three subparagraphs. In general, this exception is referred to "action".

\footnotetext{
${ }_{5}^{4}$ See https://www.wto.org/english/thewto_e/whatis_e/tif_e/org6_e.htm.

${ }^{5}$ General Agreement on Tariffs and Trade art. XXI, Oct. 30, 1947, 61 Stat. A-11, 55 UNTS 194. Art. XXI states: "Nothing in this Agreement shall be construed (a) to require any contracting party to furnish any information the disclosure of which it considers contrary to its essential security interests; or (b) to prevent any contracting party from taking any action which it considers necessary for the protection of its essential security interests (i) relating to fissionable materials or the materials from which they are derived; (ii) relating to the traffic in arms, ammunition and implements of war and to such traffic in other goods and materials as is carried on directly or indirectly for the purpose of supplying a military establishment; (iii) taken in time of war or other emergency in international relations; or (c) to prevent any contracting party from taking any action in pursuance of its obligations under the United Nations Charter for the maintenance of international peace and security".

${ }^{6}$ Alford (2011) pp. 703-704. The same "security exception" appears in GATS (art. XIV bis), and in the TRIPS (art. 73).

${ }^{7}$ GATT/CP.3/38, p. 9 .
} 
Such action can concern "fissionable materials or materials from which they are derived" (letter (b), (i)). This means that States can derogate to GATT provisions for limiting the trade of nuclear materials. This provision has been interpreted into two ways: according to a minimalist view, security exceptions are allowed only if they related to nuclear materials arising proliferations fears. According to a maximalist one, instead, the exception could be extended until covering nuclear activities used for energy needs as well. Some scholars affirm that when the GATT was negotiated, the atomic bomb had been recently launched, and thus there was the urgency of limiting nuclear materials for proliferation concerns. In reality, the specific geo-political context of the Fifties shows that in those years the quantity of fissile material available for industrial exploitation was limited. So, the countries holding it were interested in controlling the access to resources and particularly to fissionable materials for their national strategic interest, i.e. for energy needs. The non proliferation concern was not perceived before the adoption of the Treaty on the NonProliferation of Nuclear Weapons (NPT) in 1968. Anyway, the minimalist interpretation as concerning the risk of nuclear proliferation only is nowadays the most suitable interpretation of letter (b) (i), although there has been no concrete application of such subparagraph so far.

Letter (b) (ii) involves "traffic in arms, ammunition or implements of war". At first sight, the term "arms" would be refer to conventional arms. Yet, the notion has never been defined, and States have invoked it to cover strategic goods in general as related to military establishments, thus including dual-use good too. ${ }^{8}$ Again, the interpretation of the term is left upon States. It is likely that all the items listed in the different international export control regimes, ${ }^{9}$ if supplying a military establishment, are meant to be justified under art. XXI (b) (ii).

Finally, the third subparagraph (iii) takes into account actions "taken in time of war or other emergency in international relations".

The first part has been invoked, for example, in case of boycott by the Arab League to Israel (1970), for the suspension of Argentine imports into the European Community during the Falkland War between the UK and Argentina (1982), or for the embargo upon Nicaraguan products by the USA in 1985.

As a matter of example, in the case of Falkland/Malvinas War, the GATT Council justified trade embargo by the European Communities on Argentina, stating that art. XXI does not contain an obligation for Members to notify

\footnotetext{
${ }^{8}$ GATT, Analytical Index: "Guide to Law and practice”, p. 602-603. https://www.wto.org/eng lish/res_e/booksp_e/gatt_ai_e/art21_e.pdf.

${ }^{9}$ These are international fora of countries involved in the supply of dual-use items and aiming at the regulation of their trade through 'soft-law' rules and guidelines to be applied to exporters. They are: the Zangger Committee (1972-74) and the Nuclear Suppliers Group (1975), focused on nuclear items; the Australia Group (1984-85) dealing with biological and chemical items; the Wassenaar Arragement (1994) focused on conventional weapons and dualuse goods and technologies; the Missile Technology Control Regime (1987) referred to space launch vehicles and ballistic missiles. There was also the Coordinating Committee for Multilateral Export Controls (COCOM), created in 1949 and closed in 1994, because it was replaced by Wassenaar Arrangement.
} 
measures taken pursuant to the 'security exception'; however, "WTO Members should be informed to the fullest extent possible of trade measures taken under Article XXI". ${ }^{10}$

During Nicaragua-USA conflict, the GATT Panel, which was considered by some States as the body in charge with the review of the clause, as to avoid its illicit and arbitrary use, ${ }^{11}$ affirmed that embargoes "ran counter to basic aims of the GATT, namely to foster non discriminatory and open trade policies, to further the development of the less developed contracting parties and to reduce uncertainty in trade relations". ${ }^{12}$ Yet, they could be permitted for security reasons, but each State has to balance security with the maintenance of stable trade relations. Moreover, the Panel specified that it was not possible to submit the security cause to judicial review or before the WTO Dispute Settlement Body.

So, embargoes on dual-use items taken in time of war of in emergency situations could then be justified under art. XXI (b) (iii).

\section{Objective Category: Letter (c)}

Letter (c) of art. XXI GATT is the only objective category, i.e. it is not subject to States' national interpretation. It does not contain the expression "which it considers" that refers to the States' self-judgment of the existence and relevance of security needs. It affirms that if States have to comply with UN obligations, they are justified under art. XXI (c). Anyway, since this obligation derives upon States from Art. 48 UN Charter, it can be affirmed that letter (c) is mainly useless. It implies that the compliance with UN obligations is prevalent over the compliance with GATT obligations.

One meaningful case of the application of this provision can be the case of sanctions upon ex-Yugoslavia. In the Nineties, during the Balkan war, the European Communities intervened firstly breaking up peace talks, and then imposing trade sanctions on Yugoslavia through resolution 757 (1992), followed by the US embargoes. So, UN States were banned from importing and exporting with Yugoslavia. ${ }^{13}$

The same letter (c) has been invoked by India in reference to UN sanctions to Iraq, Fiji, Serbia and Montenegro. ${ }^{14}$

So far, the WTO Appellate Body and the Dispute Settlement Panels have not intervened for its interpretation. However, the doctrine considers that the States' limitations or bans to trade for security interests do not need exclusively

\footnotetext{
${ }^{10}$ See Decision of 30 November 1982, L/5426 (Dec. 2, 1982). https://www.wto.org/gatt_docs/ English/SULPDF/91000212.pdf

${ }^{11}$ Argentina, Brazil, Chile, Cuba, Czechoslovakia, India, Nicaragua, Peru, and Spain supported this position.

${ }^{12}$ Panel Report, United States - Trade Measures Affecting Nicaragua, 5.1-5.17, L/6053 (Oct. 13, 1986). http://www.wto.org/gatt_docs/English/SULPDF /91240197.pdf.

${ }_{13}$ States mention such implementation of UN measures, as authorised by art. XXI (c) GATT, in licensing notification documents. See GATT, Analytical Index, cit., p. 605.

${ }^{14}$ L/5640/Add.7/Rev.6, 18 August 1994.
} 
nor expressly the intervention of the Security Council. ${ }^{15}$ Indeed, art. XXI (c) refers to UN Charter in general and to the interventions as much as they are anchored in the defence for peace and security.

In the current situation of sanctions against Russia by the EU and the US, ${ }^{16}$ Russia has threatened to report the issue at the WTO. Although a UN SC resolution against Russia has not been approved, the EU and the US could claim to have acted in the respect of UN obligations, referring to art. XXI letter (c): indeed, Russia is continuing violating the UN General Assembly Resolution 68/262 ("Territorial integrity of Ukraine", 27 March 2014), which "calls upon all States to desist and refrain from actions aimed at the partial or total disruption of the national unity and integrity of Ukraine, including any attempts to modify Ukraine's borders through threat or use of force or other unlawful means" (paragraph 1). Yet, the EU and the US could make reference to other provisions of art. XXI GATT as well.

\section{Observations on GATT's Provisions}

Until now, there has been no GATT or WTO case law clarifying the meaning of article XXI, ${ }^{17}$ nor there is a consensus as to whether the conditions of art. XXI invoked by a State are reviewable by the WTO Dispute Settlement Body. However, even if the States have not abused of this provision so far, it would be needed to better clarify the scope and extent of such 'security exception' through a proper intervention of the competent WTO bodies, ${ }^{18}$ in order to avoid misunderstandings and mala fide interpretations. Indeed, it is evident that the provisions of art. XXI GATT is broadly written, as to leave space to States' own evaluation and interpretation of 'security', and the WTO bodies have restrained themselves from intervening.

In conclusion, it is conceivable that the limitations for trade of dual-use items and related sanctions could be allowed on the basis of art. XXI under the national interpretation of "essential security interests".

\footnotetext{
${ }^{15}$ Desierto, D. A. 2014. The EU/US v. Russia Trade Wars: Revisiting GATT Article XXI and the International Law on Unilateral Economic Sanctions. EJIL Talk (Sept. 2014). http://www.ejiltalk.org/the-euus-v-russia-trade-wars-revisiting-gatt-article-xxi-and-theinternational-law-on-unilateral-economic-sanctions-2/

${ }^{16}$ In the EU: Council Decision 2014/512/CFSP of 31 July 2014, Official Journal L 229/2014; Council Regulation (EU) No 833/2014 of 31 July 2014, in Official Journal L 229/2014; Council Decision 2014/508/CFSP of 30 July 2014, in Official Journal L 226/2014; Council Decision 2014/659/CFSP of 8 September 2014, in Official Journal L 271/2014, and Council Regulation (EU) No 960/2014 of 8 September 2014, in Official Journal L 271/2014. In the USA: Executive Order 13660 of 6 March 2014, Blocking Property of Certain Persons and Prohibiting Certain Transactions With Respect to the Crimea Region of Ukraine; Ex. Order 13661 of 17 March 2014; Executive Order 13685 of 19 December 2014.

${ }^{17}$ Barbour (2010).

${ }^{18}$ La Fortune (2014).
} 


\section{The UN System}

In general terms, UN sanctions can address States ("comprehensive or broad-based sanctions'), or single individuals/enterprises ('targeted or smart sanctions'), ${ }^{19}$ and they can be imposed for coercive purposes (when sanctions seek behavioural change from groups and individuals held responsible for an illicit behaviour), or to constrain (looking for undermining the targets' capacities to achieve their objectives), or in order to signal the disapproval of certain actions.

UN sanctions may consist of economic or non-economic measures.

The first group includes: (i) the interruption in normal economic transactions or restriction of access to economic resources for a target country. This is the case of embargo to a country, and it can be referred to all its resources ('comprehensive embargo') or to specific goods, such as arms, some services like technical assistance and trainings (this is a 'selective embargo'), ${ }^{20}$ and (ii) financial sanctions, consisting in restrictions on support for trade, and restrictions to access to capital, resources and financial transactions (asset freezes). ${ }^{21}$

Non-economic sanctions are: transport measures (preventing a person from getting a visa, or banning aircrafts from entering or transiting a country), and political and diplomatic measures (consisting in the expulsion of diplomats, the restrictions or breaking of diplomatic relationships with a country, or the suspension or expulsion of the target state from international organizations).

UN sanctions having as an object dual-use goods are economic in nature, but their aim is to obtain political or policy results, such as the determination of a change in political regime change, the blockage of a proliferation program, the end of the violation of human rights and democratic liberties, etc.

They can be legally binding (formal) sanctions and non-legally binding (informal) ones.

\section{Formal Legally Binding Sanctions: Chapter VII UN Charter and UN Resolutions}

During the phase of existence of the League of Nations, sanctions were imposed for the cross border aggression by Yugoslavia (1921); against Greece (1925); and Italy (1935) for the invasion of Ethiopia. The Covenant of the League of Nations (art. 16) stated that if any League member resorted to war against another member, all other members were immediately and automatically to subject the former to a severance of all trade and financial relations: this was a 'primitive' form of sanctions (art. 16).

Then, during the Cold War, the Security Council imposed sanctions only against Southern Rhodesia from 1965 to 1979 for its unilateral declaration of independence from Great Britain, and in the form of voluntary and mandatory

\footnotetext{
${ }^{19}$ Hufbauer and Oegg (2000).

${ }^{20}$ Chan and Drury (2000); Fruchart, Holtom and Wezeman (2007). .

${ }^{21}$ Tostensen and Bull (2002).
} 
arms embargo in 1963 and 1977 respectively, to pressure the South African regime to end apartheid. ${ }^{22}$

In the last decades, sanctions have increased, finding their legal basis in Chapter VII of the UN Charter, entitled "Action with Respect to Threats to the Peace, Breaches of the Peace, and Acts of Aggression": it states that, in case of threats to peace and security, or aggressions, the Security Council - after the initial determination of the existence of threat (art. 39) - could provide upon a State the "complete or partial interruption of economic relations and of rail, sea, air, postal, telegraphic, radio, and other means of communication" (art. 41). ${ }^{23}$

Before opting for Chapter VII, it is proper that the SC acts under Chapter VI (Pacific settlement of Disputes), as art. 41 represents an extrema ratio.

It is conceivable that the SC may decide to interrupt economic relations with the countries possessing Weapons of Mass Destruction (WMD), or that are liable for trading and having sensitive commodities and dual-use items, as long as the possession/trade represents a breach to peace and security.

When the SC decides for imposing sanctions, it should take into account the respect of the purposes and principles of the UN (art. 24 UN Charter), the principles of justice and international law (art. 1.1), equal rights and selfdetermination of peoples (art. 1.2) and the respect of other human rights (art. $55)$.

The SC exercises its power through Resolutions, ${ }^{24}$ whose adoption requires a majority of 9 of the 15 members, and no veto by any of the five permanent members.

Along with the enactment of the resolution, a Sanctions Committee for monitoring the implementation of sanctions is established, ${ }^{25}$ as well as a Panel of Experts to assist the Committee. These two bodies release reports by consensus. There is also a SC Subsidiary Organ Branch, placed in the SC Affairs Division, which is responsible for the monitoring of the implementation of sanctions.

Such resolutions are compulsory for all UN members on the basis of art. $2.5,25$, and 48.1 of the UN Charter. Even UN non members are called upon to cooperate for the implementation of resolutions, according to art. 2.6.

A tendency can be observed in the field of sanctions: during the Cold War and until the Nineties, the preference was given to comprehensive sanctions

\footnotetext{
${ }^{22}$ Hufbauer, Schott, and Elliott (1990) pp. 24-25, 33-34, 285-286.

${ }^{23}$ A limited role is recognised upon the Assembly General, which can decide on the expulsion of a State from the UN, or the suspension of its rights because of violation of the measures decided by the SC. This power based on art. 5 of UN Charter has never been exercised. Moreover, the AG can recommend some restrictive measures towards a State, but the SC is not obliged to adopt them.

${ }^{24}$ For all the resolutions, see http://www.un.org/en/sc/documents/resolutions/.

${ }^{25}$ Sanction Committees are pursuant to art. 29 of UN Charter and Rule 28 of the Security Council's provisional rules of procedure.
} 
referred to the whole target State, ${ }^{26}$ as it occurred for cases of nuclear proliferation, civil wars and cross-border conflicts, terrorism. Then, because of the humanitarian consequences of sanctions affecting indiscriminately the non responsible civilians, the UNSC preferred addressing specific listed people and groups. ${ }^{27}$ In this latter hypothesis, Member States usually propose targeted candidates to the Sanctions Committees. They are listed if they constitute a threat to peace, security or stability, violate an arms embargo, support armed groups through illegal commodity trade, and boost WMD proliferation.

With regards to sanctions on dual-use items, it can be noted that the UN has never mentioned the expression 'dual-use' as such, nor has it given a definition. This has occurred because the notion is quite fuzzy and the continuous evolution of the science and technology does not permit to offer a workable definition. Moreover, providing an embargo on dual-use items generically considered would not be proportional, as it could cover too many goods. Therefore, the UNSC has preferred imposing sanctions on a case-bycase basis upon specific goods, or it has made reference to lists of items already disposed within export control regimes and fora.

Historically speaking, the UN has prevented the States from exporting to Iran and Iraq chemical weapons and related products that could be used for the production of Weapons of Mass Destruction (resolution 612 (1988)). Then, in resolution 687 (1991) Iraq was requested to destroy and remove all the WMD arsenals (chemical and biological arsenals, and ballistic missiles: paragraph 8), and it was subject to an embargo on WMD dual-use related items, technology and materials (paragraphs 10, 12, 20 and 24).

In case of Iran, resolution 1696 (2006) required States to "prevent the transfers of any items, materials, good and technology that could contribute to Iran's enrichment-related and reprocessing activities and ballistic missile programmes" (paragraph 5). Resolution 1737 (2006) added the prohibition of technical or financial assistance, training, or resources related to certain nuclear and ballistic missile-related goods (paragraph 6), while the further resolution 1747 (2007) banned the supply, sale, or transfer of major military weapons systems and related material to Iran (paragraph 6), and it prevented the entry or transit of people involved with Iran's proliferation sensitive nuclear activities or in the development of nuclear weapon delivery systems, such as for the procurement of the prohibited dual-use items, goods, equipment, materials and technology (paragraph 2).

The reference to export control lists of items has occurred in the context of sanctions against the Democratic People's Republic of Korea (DPRK): ${ }^{28}$ for

\footnotetext{
${ }^{26}$ UN Security Council. 2013. Special Report (Nov. 2013), p. 3. http://www.securitycouncil report.org/atf/cf/\%7B65BFCF9B-6D27-4E9C-8CD3CF6E4FF96FF9\%7D/special_research_report_sanctions_2013.pdf

${ }^{27}$ In 1998/1999 at the Interlaken Process the focus was posed on targeted financial sanctions; at the Bonn-Berlin Process (1999/2000) on travel and air traffic related sanctions; and at the Stockholm Process on the implementation and monitoring of targeted sanctions (2002/2003). See Fernandez (2012).

${ }^{28}$ See also resolution 1695 (2006) which required the States to prevent missile and missilerelated items, materials, goods and technology being transferred to DPRK's missile or WMD
} 
example, resolution 1718 (2006) provided an embargo on items as set out in the Nuclear Suppliers Group Lists and Missile Technology Control Regime (MCTR), also taking into account Australia Group list, and it banned any form of transfer and procurement of those items (paragraph 8 (a) and (b)).

As for targeted sanctions having a link with dual-use goods, States have been prevented from sale, supply, or transfer the chemical acetic anhydrite to any person in the territory of Afghanistan under Taliban control (through resolution 1333 (2000), paragraph 10, and resolution 2160 (2014) paragraph 9).

\section{Informal Sanctions at the UN Level}

Security Council can deal with sanctions in an informal way too, i.e. through Presidential Statements, which are not legally binding for UN States. They are not even envisaged in the UN Charter but developed in the practice, and they are adopted at a formal meeting of the Council and issued as an official document of the Council. ${ }^{29}$

Presidential Statements usually condemn certain situations and call upon for deeper measures. For instance, in case of North Korea, several statements have strongly condemned the DPRK's activities, such as the statement in April 2012, ${ }^{30}$ directing the Sanctions Committee to take steps to update and strengthen the sanctions regime, or the statement condemning the 26 March 2010 attack which led to the sinking of the ROK naval ship Cheonan, ${ }^{31}$ or the one against the 5 April 2009 launch of a rocket by DPRK. ${ }^{32}$ In case of Iran, likewise, the SC has expressed his condemnation for nuclear activities and requested Iran to suspend all activities related to nuclear enrichment and reprocessing, including research and development, to be verified by the IAEA. $^{33}$

Presidential Statements sometimes intervene on targeted sanctions too.

The explicit imposition or termination of sanctions has never occurred through a Presidential Statement, but it has been an instrument for preceding or confirming those decisions assumed by the SC, thus working as a complement to the content of a SC resolution. In reality, they are preferred when the UNSC cannot reach consensus, or it is blocked by veto for adopting a resolution.

The adoption of these Statements requires consensus, although Security Council members may abstain.

\section{Observations on the UN Regime}

The main problem of UN sanctions is the issue of implementation and enforcement of sanctions: indeed, in the international society there are no

programmes, as well as the procurement of those items, and any financial resources in relation to DPRK's missile or WMD programmes (paragraphs 3 and 4).

${ }^{29}$ See Talmon (2003).

${ }^{30}$ Statement, 16 April 2012, S/PRST/2012/13.

${ }^{31}$ Statement, 9 July 2010, S/PRST/2010/13.

${ }^{32}$ Statement 13 April 2009, S/PRST/2009/7.

${ }^{33}$ Statement 9 March 2006, S/PRST/2006/15. 
public authorities with executive, police and judicial powers like the ones in national States. As known, the international community is still a system of States claiming for sovereignty, and based on the States' voluntary acceptance of committing to international rules. Therefore, the enforcement of adopted sanctions remains weak, despite the draft of recommendations that boost for better systems of monitoring. ${ }^{34}$ The UN tries to engage other organizations in the control phase, such as the IAEA (e.g., the case of the verification of Iran's compliance with resolution 2231 (2015)), or through the creation of Special Commissions (such as the International Commission of Inquiry, UNICOI, established by resolution 1013 (1995) for the control of the supply of arms and materials to Rwandan government forces). However, it results that the ultimate controller of sanctions is the SC itself.

Another issue is the lack of clarity of some terms, which can create discrepancies among States, or the broad margin of appreciation left to States. For instance, in case of resolution 1737 (2006) against Iran, States have the right to choose which items of the Nuclear Suppliers Group dual-use control list would contribute to enrichment-related, reprocessing or heavy waterrelated activities.

Moreover, some UN sanctions regimes have appeared not to properly protect the human rights of targeted people, who have claimed the violation of their rights to due process. Because of the importance of international and regional human rights law, the UN has felt the need to strengthen human rights in the context of sanctions too through the creation of Focal Points for Delisting (established within the Secretariat by resolution 1730 (2006)) and the inauguration of the Office of the Ombudsperson (by resolution 1904 (2009) to review delisting requests for the Al-Qaida regime only, and recently with res. 2253 (2015) for ISIL (Da'esh) regime too). However, despite the existence of these two bodies, the system still needs improvements: the Focal Point has demonstrated scarce effective results, and the Ombudsman has a limited mandate. ${ }^{35}$ Yet, the proposals to expand their role have been blocked. ${ }^{36}$

A central topic is the effectiveness of sanctions, i.e. sanctions' capacity to produce the effects they pursue. Indeed, sanctions can determine consequences at the political, economic, social and humanitarian level (e.g., the increase of authoritarian powers and corruption, inflation, recession, poverty, deterioration of living conditions, etc.), and these effects could sometimes affect neighbouring States or third States too in unexpected ways, such as favouring other markets. It is, thus, important to evaluate a priori the intensity of sanctions, and define clearly their strategic objectives. In this sense, it is also central that the SC or other UN bodies verify and progressively and constantly check the impact of sanctions.

\footnotetext{
${ }^{34}$ UN Security Council. 2006. Report of the Informal Working Group of the Security Council on General Issues of Sanctions. Doc. S/2006/997 (Dec. 22, 2006). http://www.securitycouncil report.org/atf/cf/\%7B65BFCF9B-6D27-4E9C-8CD3CF6E4FF96FF9\%7D/WG\%20Sanctions\%20S2006997.pdf

${ }^{35}$ Hovell (2016).

${ }^{36}$ See UN Doc. S/2014/725, Concept Paper on Security Council Working Methods (Oct. 8, 2014), discussed on the Security Council Working Methods, 7285th Meeting of the SC.
} 
Some scholars suggest that, in order for sanctions to be effective, they should be part of a broader strategy, as they are not a panacea, and require cooperation inside the UN bodies, and with external stakeholders, such as the States and civil society for their implementation. ${ }^{37}$

\section{Brief Observations on the European Union Level}

The framework of trade sanctions enacted at the international level is complemented by regional sanctions, such as at the European Union level, where a specific sanctions policy towards third countries exists.

Similarly to the UN level, restrictive measures have addressed both the countries as such and targeted individuals. Here again two categories of sanctions can be individuated: (a) formal ones, adopted in the Common Foreign and Security Policy (CFSP) framework, through a Council Decision, eventually followed by a Regulation ${ }^{38}$; and (b) informal ones, introduced outside the CFSP, and mainly having have a diplomatic, political or financial nature (with the only exception of an arms embargo to China, imposed informally in 1989 through a Presidential Statement).

The first category, in particular, shows the role of the EU in: (i) 'rewriting' the UNSC resolutions into EU law, thus giving implementation to them (for example, Common Position 2003/495/CFSP on Iraq); (ii) supplementing the UN measures (e.g., Council Decision 2011/235/CFSP and Council Regulation (EU) No 267/2012 against Iran); and (iii) autonomously formulating EU measures, without an international precedent (for instance, Council Decision 2014/145/CFSP against Russia). ${ }^{39}$

In reference to dual-use goods, the EU has adopted sanctions against Iran, Syria and North Korea, such as the Council Decision 2010/413/CFSP prohibiting direct or indirect supply, sale or transfer to Iran of materials listed in the Nuclear Suppliers Group, in the Missile Technology Control Regime lists, in the Regulation 428/2009 (known as the "EU dual-use regulation") and in UNSC resolutions; Council Decision 2011/782/CFSP against Syria, prohibiting the export of certain dual use items related telecommunication or internet monitoring or interception items and technology, and Regulation 509/2012 on dual-use chemicals; and the recent Council Regulation (EU) 2016/682 against North Korea, making reference to WMD goods and prohibited dual-use items. $^{40}$

\footnotetext{
${ }^{37}$ Elliott (1998).

${ }^{38}$ It depends on the object of the sanctions: indeed, if the sanctions consist of a general embargo (included embargo on dual-use items), or financial measures, the Council Decision adopted on the basis of art. 29 TEU - should be followed by a Regulation pursuant to art. 215.1 TFEU; otherwise, if the objects are arms embargoes or travel bans, the Council Decision is directly implemented by Member States and no other act is needed. With reference to sanctions against individuals, they are taken on the basis of art. 215.2 and art. 75 TFEU.

${ }^{39}$ For the list of EU sanctions, see: http://eeas.europa.eu/cfsp/sanctions/docs/measures_en.pdf.

40 The role of the European Court of Justice in the area of sanctions is meaningful, and it should be taken into account in the interpretation of regimes: See, for example, as for Iranian
} 


\section{Some Critical Remarks}

The analysis developed above shows that dual-use items need measures of control. They are placed at the intersection at commercial rules, and foreign policy and security interests: indeed, it is needed to find a balance between the allowance of business, and the worries that some items can be commercialised in order to be used with malevolent purposes. It explains why the international and regional organizations (as well as single Member States) have taken an active role in the issues of trade control involving dual-use goods. However, by virtue of their different mission, the organizations have assumed different positions.

The WTO, because of its vocation to ensure free trade, has taken into account security needs in the regulation of commerce, but from a trade-focused perspective, and thus it has left broad space to States and to their policies of national sovereignty. Indeed, the GATT provisions are quite vague on the definitions of terms, and in particular of the expression "essential security interests", which is the 'key brick' for triggering the limitations to trade of dual-use items, theoretically allows for many interpretations by States. Such formula could be used in arbitrary ways too, and so it is important to control possible slippery slopes in that sense.

What emerges in the WTO context is thus the big margin of intervention for States, which is more limited in the UN: here the focus is posed on peace and security, as these are the core values at the basis of the mission of the organization, and so even commercial relationships and networks are evaluated under this viewpoint. For this reason, the UN is more prone to intervene on trade of dual-use items when (and provided that) they threaten international peace. However, it does not mean that the States have no role at all: on the contrary, as known, the international community is still composed on sovereign countries. Therefore, States possess a relevant duty in the implementation and application of UN sanctions, even if mechanisms for ensuring the effective compliance are lacking and it should be improved.

At the regional level, the existing agencies and organizations could be the longa manus of international organizations for applying sanctions: the EU, for instance, has positioned itself at the avant-garde in the promotion of UN values in the trade field as well, and has demonstrated to be very active in shaping autonomous measures, in the name of peace. Even if it is born for commercial reasons, in the course of time it has broadened its horizons to cover foreign policy issues too. However, the reluctance of many States to recognise the role of the EU in this direction and to renounce to pieces of their sovereignty makes it difficult to ensure an effective system of sanctions. Therefore, the EU sanctions regimes should be optimised and implemented.

entities, case T-181/13, Sharif University of Technology v Council; case T-494/10, Bank Saderat Iran v Council; case T-35/10, Bank Melli Iran v Council; case T-13/11, Post Bank Iran v Council. 


\section{Conclusions}

The analysis conducted above shows that the category of dual-use items requires a particular attention within trade law. Indeed, their sensitiveness in terms of security concerns is not negligible.

Dual-use goods challenge the "free trade dogma" which is dominant in trade law, and demand specific measures of control, in order to avoid especially the proliferation concerns that they may arise (in relation to Weapons of Mass Destruction).

Sanctions can be considered as an interesting method in this regard.

At the international level, sanctions having as an object dual-use goods find their legal basis in the WTO context, in particular art. XXI GATT, which provides an exception on liberalism for security reasons. On the other hand, one of the most prolific and active actors of sanctions covering dual-use items too has been the UN Security Council, which has intervened in several occasions, through embargoes and targeted measures on individuals or groups trading these items.

At the regional level, then, in particular in the European territorial space, it is evident the role of the European Union, both for implementing UN measures and for imposing autonomous ones.

All this demonstrates that there exists a multi-level framework of dual-use related sanctions. Despite the difficulties in their implementation and monitoring, sanctions may represent a significant contribution in the need for guaranteeing security and peace in the world.

\section{References}

Alford, R.P. (2011). 'The Self-Judging WTO Security Exception' in 2011 Utah Law Review 3: 697-759.

Atlas, R.M. and M.R. Dando (2006). 'The 'Dual-use Dilemma' for the Life Sciences: Perspectives, Conundrums, and Global Solutions' in 2006 Biosecurity Bioterrorism. 3, 4:276-286.

Barbour, E.C. (2010). Trade Law: An Introduction to Selected International Agreements and U.S. Law. Congressional Research Service, Washington, DC.

Chan, S. and A.C. Drury (2000). 'Sanctions as Economic Statecraft: an Overview', in Sanctions as Economic Statecraft: Theory and Practice (S. Chan and A. C. Drury, eds.) Palgrave Macmillan Press, New York, NY, 1-16.

Desierto, D.A. (2014). The EU/US v. Russia Trade Wars: Revisiting GATT Article XXI and the International Law on Unilateral Economic Sanctions. EJIL Talk (Sept. 2014). http://www.ejiltalk.org/the-euus-v-russia-trade-wars-revisiting-gattarticle-xxi-and-the-international-law-on-unilateral-economic-sanctions-2/

Elliott, K.A. (1998). The Sanctions Glass: Half Full or Half Empty?. International Security 23(1): 50-65.

Fernandez, J.W. (2012). Smart Sanctions: Confronting Security Threats with Economic Statecraft. http://www.state.gov/e/eb/rls/rm/2012/196875.htm

Fruchart, D., Holtom, P. and S.T. Wezeman (2007). United Nations Arms Embargoes. Their Impact on Arms Flows and Target Behaviour. Stockholm International 
Peace Research Institute (SIPRI) and the Department of Peace and Conflict Research, Uppsala, Sweden.

Hovell, D. (2016). The Power of Process: The Value of Due Process in Security Council Sanctions Decision-Making. Oxford University Press, Oxford, UK.

Hufbauer, G.C. (1997). Economic Sanctions: America's Folly. Transcript of the Presentation before the Council of Foreign Affairs, Nov. 10, 1997. http://www.cfr.org/trade/economic-sanctions-americas-folly/p62

Hufbauer, G.C. and B. Oegg (2000). Targeted Sanctions: A Policy Alternative?. Paper for a symposium on 'Sanctions Reform? Evaluating the Economic Weapon in Asia and the World', Febr. 23, 2000. https://www.piie.com/publications/papers/ paper.cfm?ResearchID $=371$

Hufbauer, G.C., Schott, J. and K.A. Elliott (1990). Economic Sanctions Reconsidered. Supplemental Case Histories. Peterson Institute for International Economics, Washington, DC.

Irwin, D.A., Mavroidis, P.C., and A.O. Sykes (2009). The genesis of the GATT. Cambridge University Press, Cambridge, UK.

La Fortune, G. (2014). WTO Rules and Sanctions on Russian Trade. Oct. 9, 2014. http://www.wl-tradelaw.com/wto-rules-and-sanctions-on-russian-trade/

Talmon, S. (2003). 'The Statements of the President of the Security Council' in Chinese Journal of International Law 2 (2): 419-466.

Tostensen, A. and B. Bull (2002). 'Are Smart Sanctions Feasible?' in World Politics 54:3:373-403. 
